This article was published on 2 Feb 2021 at www.hkmj.org.

\title{
COVID-19 primary care response and challenges in Singapore: a tale of two curves
}

\author{
Y Liow ${ }^{1,2}$ *, MB, BS, MMed, Victor WK Loh², MMed, MHPE, LH Goh², MB, BS, MMed, David HY Tan ${ }^{1,2}$, MB, BS, MMed, \\ TL Tan ${ }^{2,3}$, FRCPE, FCFPS, CK Leong ${ }^{2,4}$, MMed, FAMS, Doris YL Young', MB, BS, MD \\ ${ }^{1}$ National University Polyclinics, National University Health System, Singapore \\ ${ }^{2}$ Division of Family Medicine, Yong Loo Lin School of Medicine, National University of Singapore, Singapore \\ ${ }^{3}$ The Edinburgh Clinic, Singapore \\ ${ }^{4}$ Mission Medical Clinic, Singapore \\ *Corresponding author: yiyang_liow@nuhs.edu.sg
}

Hong Kong Med J 2021;27:70-2

\section{Introduction}

As global cities with comparable healthcare systems and shared experience of the 2003 Severe Acute Respiratory Syndrome outbreak, Hong Kong and Singapore have had contrasting fortunes in flattening their respective coronavirus disease 2019 (COVID-19) epidemic curves. Both reported their first cases 1 day apart in late January 2020 and quickly implemented border entry restrictions and quarantine orders to limit imported cases. Hong Kong adopted other aggressive interventions such as school closures, ${ }^{1}$ whereas Singapore opted for a more measured initial approach that included advising only those unwell to wear face masks. ${ }^{2}$ Hong Kong flattened its curve by the end of March; despite early success, Singapore grappled with the emergence of two distinct curves: one representing the Singapore community population and another representing the migrant worker dormitory population $\left(\mathrm{Fig}^{3}\right)$. This commentary presents the duality of the COVID-19 situation in Singapore and discusses the related primary care response and challenges.

\section{Primary care in Singapore}

Located in Southeast Asia, Singapore is an island city-state with a population of more than 5.7 million. Primary care forms the foundation of its healthcare system. Similar to Hong Kong, the majority (about $80 \%)$ of primary care services are provided by 1700 privately run clinics, which range from sole proprietor to large group practices. The remaining demand is met by 20 community-based healthcare centres known as 'polyclinics', which are similar to General Outpatient Clinics in Hong Kong. These operate with

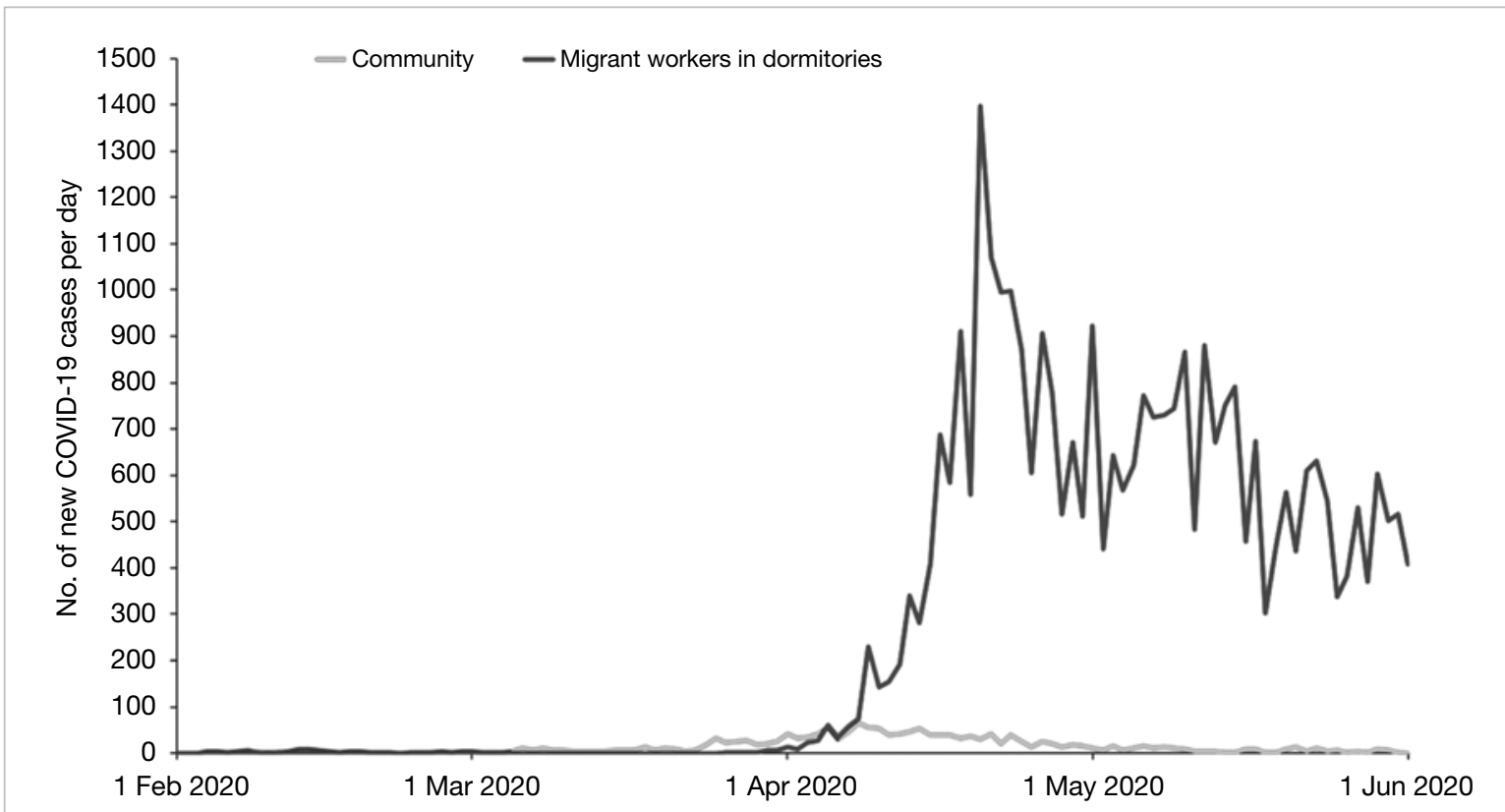

FIG. Epidemic curves showing the number of daily new cases of coronavirus disease 2019 in the community and among migrant workers in dormitories in Singapore from I February to I June $2020^{3}$ 
government subvention to provide subsidised care based on citizenship status. ${ }^{4}$ Whereas the private sector handles almost $90 \%$ of acute visits, polyclinics see more than $40 \%$ of chronic disease attendances. ${ }^{5}$

\section{Community curve}

When local transmission was detected in Singapore in early February 2020, authorities activated the Public Health Preparedness Clinics (PHPC), an island-wide network of more than 900 primary care clinics and polyclinics. Patients with acute respiratory symptoms received subsidised treatments at these clinics, which increased accessibility to care. This resulted in more than $70 \%$ of confirmed cases visiting a clinic within 2 days of symptom onset. ${ }^{6}$ Those who met suspect case criteria were tested under the 'Swab-and-SendHome' (SASH) programme. The SASH facilitated outpatient management, increased testing capacity, and reduced the burden on tertiary centres. The network also served an epidemiological role by gathering data on community transmission including performing sentinel surveillance swabs. Together with other public health measures and the 'circuit breaker', which was an enhanced set of social distancing measures introduced by the Singapore Government in early April including closure of schools and nonessential workplaces, the PHPC helped to flatten the community curve by end May $2020{ }^{7}$

The immediate challenge faced by primary care physicians from the PHPC was introducing infection control measures, including creating segregation protocols and well-ventilated isolation areas. These were operational challenges, particularly for smaller practices with limited resources. A global shortage of personal protective equipment also meant that clinics had to ration supplies. Keeping abreast of new advisories and workflows was another challenge. For instance, SASH was initially restricted to patients with clinical or radiological features of communityacquired pneumonia. However, as evidence emerged of pre-symptomatic transmission ${ }^{8}$ and mild disease in the early stages, the SASH criteria were expanded accordingly. At activated PHPC centres, physicians encountered patients who had visited other clinics and had not improved. More than $20 \%$ of the first 160 confirmed cases visited more than one clinic. ${ }^{9}$ 'Doctor hopping' disrupted continuity of care and risked cross contamination between clinics. Proper messaging through mainstream and social media channels helped reduce such behaviour. ${ }^{10}$ As COVID-19 emerged, cases of dengue fever, which is endemic in Singapore, were at a 4 -year high. ${ }^{11}$ Both viral infections have significant overlap in clinical and laboratory features. ${ }^{6}$ Primary care physicians had to be mindful of this dual outbreak as well as 'covert' COVID-19 masquerading as false-positive dengue serology. ${ }^{12}$

\section{Migrant worker dormitory curve}

Originating mainly from India, Bangladesh, and China, migrant workers in Singapore are employed in industries such as construction and manufacturing. There are about 323000 residing in close proximity to each other in 43 purpose-built dormitories. ${ }^{13}$ Worksites often engage workers living in different dormitories and hence a single case can lead to multiple clusters. Despite precautions taken to restrict socialisation, more than 35000 such workers have been infected. Outposts in dormitories were erected to screen workers and meet their medical needs. Facilities island-wide including hotels and exhibition centres were converted to isolation centres to house those affected. Primary care physicians, who are trained to provide care across multiple settings in the community, were mobilised to these sites. Many from public and private sectors, as well as locum and retired practitioners, volunteered their efforts. Some brought essential experience, having previously cared for migrant workers as designated workplace doctors or practising in industrial areas and non-profit clinics catered to migrant workers.

One of the first challenges faced by primary care physicians delivering care on-site was the language barrier. Many workers spoke little or no English, the working language of Singapore, which impaired communication. Physicians overcame this through visual aids, translators, and smartphone applications. ${ }^{14}$ Although the majority of workers are young and healthy, some are middle-aged with chronic conditions such as hypertension and diabetes mellitus. Some were being managed by physicians in their home countries with care invariably affected by disruption due to the pandemic. These conditions had to be managed carefully with given resources. The workers' mental health also had to be monitored closely with concerns of 'cabin fever' from prolonged isolation progressing to more serious depressive and anxiety disorders. New cases are still being recorded daily and with authorities' plans to test every worker, primary care physicians will continue playing an important role in flattening this curve. ${ }^{15}$

\section{Conclusion}

Singapore's tale of two curves has important lessons. Firstly, containment and mitigation strategies are effective in flattening COVID-19 epidemic curves. ${ }^{16}$ As borders and economies reopen, measures with the most benefit and least cost to society may need reinstating. Secondly, accessible and coordinated primary care continues to be a key arm of the response to public health emergencies. Authorities must continue to engage physicians and other stakeholders regularly and should do so even during 'peace time'. Lastly, every precaution must be taken to 
protect groups who live communally, such as migrant workers. Singapore must look again at how these workers are housed. The magnitude of the dormitory curve should be a stark warning to other nations with similar groups.

\section{Author contributions}

Concept or design: Y Liow, WKV Loh, DYL Young.

Acquisition of data: $\mathrm{Y}$ Liow.

Analysis or interpretation of data: All authors.

Drafting of the manuscript: All authors.

Critical revision of the manuscript for important intellectual content: All authors.

All authors had full access to the data, contributed to the study, approved the final version for publication, and take responsibility for its accuracy and integrity.

\section{Conflicts of interest}

The authors declare no conflicts of interest.

\section{Acknowledgement}

The authors would like to thank Ms Monica Ashwini Lazarus, Department of Family Medicine, Yong Loo Lin School of Medicine, National University of Singapore, for editing a draft of this manuscript.

\section{Funding/support}

The authors received no specific grant from any funding agency in the public, commercial, or not-for-profit sectors, in relation to this commentary.

\section{References}

1. Cowling BJ, Ali ST, Ng TW, et al. Impact assessment of non-pharmaceutical interventions against coronavirus disease 2019 and influenza in Hong Kong: an observational study. Lancet Public Health 2020;5:e279-88.

2. Goh T. Wuhan virus: Masks should be used only by those who are unwell. The Straits Times. 31 Jan 2020. Available form: https://www.straitstimes.com/singapore/health/ masks-should-be-used-only-by-those-who-are-unwell. Accessed 31 Jan 2020.

3. Ministry of Health, Singapore Government. COVID-19 interactive situation report. 2020. Available from: https:// www.moh.gov.sg/covid-19/situation-report. Accessed 9 Jun 2020.

4. Ministry of Health, Singapore Government. Primary healthcare services. 2018. Available from: https://www. moh.gov.sg/home/our-healthcare-system/healthcareservices-and-facilities/primary-healthcare-services.
Accessed 9 Jun 2020.

5. Ministry of Health, Singapore Government. Primary Care Survey 2014 Report. Available from: https://www.moh. gov.sg/resources-statistics/reports/primary-care-survey2014-report. Accessed 8 Jun 2020.

6. Lam LT, Chua YX, Tan DH. Roles and challenges of primary care physicians facing a dual outbreak of COVID-19 and dengue in Singapore. Fam Pract 2020;37:578-9.

7. Ministry of Health, Singapore Government. Circuit breaker to minimise further spread of COVID-19. $3 \mathrm{Apr}$ 2020. Available from: https://www.moh.gov.sg/newshighlights/details/circuit-breaker-to-minimise-furtherspread-of-covid-19. Accessed 9 Jun 2020.

8. Wei WE, Li Z, Chiew CJ, Yong SE, Toh MP, Lee VJ. Presymptomatic transmission of SARS-CoV-2-Singapore, January 23-Mar 16, 2020. MMWR Morb Mortal Wkly Rep 2020;69:411-5.

9. Singapore Government. COVID-19 spread caused by socially irresponsible behaviour. 11 Mar 2020. Available from: https://www.gov.sg/article/covid-19-spread-causedby-socially-irresponsible-behaviour. Accessed 9 Jun 2020.

10. Singapore Government. Steps to take when you're unwell. 23 Mar 2020. Available from: https://www.gov.sg/article/ steps-to-take-when-youre-unwell. Accessed 9 Jun 2020.

11. Ng JS. Dengue cases at four-year high. Today Online. Available from: https://www.todayonline.com/singapore/ dengue-cases-four-year-high. Updated 12 Feb 2020. Accessed 11 Feb 2020.

12. Yan G, Lee CK, Lam LT, et al. Covert COVID-19 and falsepositive dengue serology in Singapore. Lancet Infect Dis 2020;20:536

13. Ministry of Manpower, Singapore Government. List of foreign worker dormitories. 2020. Available from: https://www.mom.gov.sg/passes-and-permits/workpermit-for-foreign-worker/housing/foreign-workerdormitories\#/?page=1\&q. Accessed 9 Jun 2020.

14. Yip C. 'Your website will save lives': NUS graduate builds translation portal for medical teams treating migrant workers. Channel News Asia: International Edition. CNA Insider. 17 Apr 2020. Available from: https://www. channelnewsasia.com/news/cnainsider/covid-19-nusmedical-graduate-bengali-translators-workers-12650406. Accessed 17 Apr 2020.

15. Sin Y. All foreign workers in dorms to be tested for Covid-19. The Straits Times. 13 May 2020. Coronavirus pandemic. Available from: https://www.straitstimes.com/ singapore/all-foreign-workers-in-dorms-to-be-tested-forcovid-19. Accessed 13 May 2020.

16. Walensky RP, Del Rio C. From mitigation to containment of the COVID-19 pandemic: putting the SARS-CoV-2 genie back in the bottle. JAMA 2020;323:1889-90. 